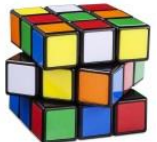

УДК: 159.99:316.46:371.8
Лідер. Еліта.Суспільство

Leader. Elite. Society

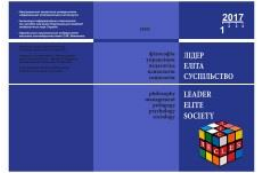

doi: 10.20998/2616-3241.2021.1.05

\title{
Ніна Підбуцька
}

доктор психологічних наук, професор, професор кафедри педагогіки і психології управління соціальними системами ім. академіка І. Зязюна, Національний технічний університет "Харківський політехнічний інститут”;

Харків, Україна

ORCID: 0000-0001-5319-1996

E-mail:podbutskaya_nina@ukr.net

\section{Анастасія Книш}

кандидат психологічних наук, доцент, доцент кафедри педагогіки і психології управління соціальними системами ім. академіка І. Зязюна, Національний технічний університет "Харківський політехнічний інститут”;

Харків, Україна

ORCID: 0000-0003-0211-2535

E-mail:n_knysh@ukr.net

\section{ГЕНДЕРНІ ОСОБЛИВОСТІ ПОЛІКОМУНІКАТИВНОЇ ЕМПАТІЇ СТУДЕНТІВ-ЛІДЕРІВ}

Анотація: розглянуто проблему прояву полікомунікативної емпатії у студентів, що характеризуються вираженими лідерськими якостями. Було проаналізовано роль емпатії в становленні лідерського стилю студентів. В ході дослідження було визначено, щзо емпатія є однією з найбільш важливих рис в структурі особистості сучасного студентського лідера, а ї̈ формуванню має приділятися особлива увага в закладах вищої освіти. Емпіричне дослідження лідерських здібностей дозволило визначити, щяо близько 29\% студентів володіють вираженими на високому рівні лідерськими здібностями. Аналіз гендерних особливостей прояву полікомунікативної емпатії студентів-лідерів дозволив визначити, щчо у дівчат емпатія розвинена краще, ніж у хлопиів. В статті наводяться перспективні напрямки розвитку теми дослідження.

Ключові слова: лідер, лідерство, емпатія, полікомунікативна емпатія, гендер, студенти, майбутні фахівці.

\section{Nina Pidbutska}

doctor of psychological sciences, professor, professor of the department of pedagogy and psychology of management of social systems academician I. Zyazyun,

National Technical University "Kharkiv Polytechnic Institute";

Kharkiv, Ukraine

Email: podbutskaya_nina@ukr.net 


\title{
Anastasia Knysh
}

candidate of psychological sciences, associate professor, associate professor of pedagogy and psychology of management of social systems academician I. Zyazyun,

National Technical University "Kharkiv Polytechnic Institute";

Kharkiv, Ukraine

Email:n_knysh@ukr.net

\section{GENDER FEATURES OF POLYCOMMUNICATIVE EMPATHY OF LEADING STUDENTS}

\begin{abstract}
: the article considered the problem of manifestation of polycommunicative empathy in students with strong leadership qualities. The role of empathy in the formation of students' leadership style was analyzed. The study found that empathy is one of the most important features in the personality structure of a modern student leader, and its formation should be given special attention in higher education institutions. An empirical study of leadership skills revealed that about $29 \%$ of students have a high level of leadership skills. The analysis of gender peculiarities of the manifestation of polycommunicative empathy of students-leaders allowed to determine that empathy is better developed in girls than in boys. The article presents promising areas of development of the topic.
\end{abstract}

Key words: leader, leadership, empathy, polycommunicative empathy, gender, students, future specialists.

\section{Nina Pidbutska, Anastasiia Knysh}

\section{An extended abstract of the paper on the subject of: "Gender features of polycommunicative empathy of student leaders"}

Problem setting. The urgency of the topic of educational leadership is due to the fact that the strategy for the development of higher education in Ukraine for 2021-2031, leadership is defined as one of the important areas of professional development. It is difficult to overestimate the role of educational leadership in the process of forming a modern specialist. Research conducted around the world indicates that student leadership promotes the development of high learning outcomes, entrepreneurial skills, communication skills. Purposeful leadership development programs help create an atmosphere of greater student involvement in the educational process. However, researchers agree that the development of all these indicators could be facilitated not only by leadership development programs or the presence of strong leaders in groups, but also favorable conditions for self-development on campus or active social interaction between participants in the educational process. At the same time, researchers from all over the world agree with the fact that student leaders who are ready to boldly demonstrate their views, positions, beliefs can act as role models for their followers. In this context, the ability of student leaders not only to realize the moods and interests of their followers, but also to literally feel them, plays an extraordinary role. This ability can provide a developed empathy. By over-focusing on research into the willpower, intellectual qualities of leaders, researchers often forget that leadership is a social phenomenon, and its success depends on the quality of interpersonal communication between leader and followers, based on empathy.

Recent research and publications analysis. Recent research shows that student leadership is a very heterogeneous pheno- 
menon that brings together people with different personalities, aspirations, goals, and responsibilities. It is very important that the type of leadership to which students belong contributes to the constructive development of their followers and creates conditions for the demonstration of positive learning models. In our study, we rely on the definition of leadership proposed by O. Romanovsky: "Leadership is a threecomponent phenomenon: leadership as a person; leadership as a team; leadership as a process. The combination of certain components ensures the consistent movement of the leader and his team to achieve the goal and achieve the objectives. The absence of at least one of the components leads to the blocking of the realization of the leadership potential of the individual".

In determining the type of educational leadership, such characteristics of student leaders as empathy are extremely important. The broadest definition of empathy was proposed by R. Bar-On, who defined it as the ability to deeply feel the emotional states, goals and values of others, accompanied by a desire to support other people and help when needed.

In the works of N. Pidbutska the importance of empathy in the context of the formation of professionalism of the individual is considered. The researcher proves that empathy as one of the indicators of the emotional sphere of a person plays a decisive role in the formation of a mature person who is able to demonstrate social responsibility and consistency. Leading students need more than anyone else to develop this aspect of professionalism, because their integrity, responsibility, ability to adhere to their own values depends not only on their own success, but also the success of their followers.

Paper objective was to present the results of the study of gender characteristics of polycommunicative empathy of student leaders.

Paper main body. In order to realize the purpose and objectives of the article, we conducted a study with the participation of 214 students of the National Technical University "Kharkiv Polytechnic Institute". The study was conducted in two stages.

At the first stage, students were tested using the method of "Diagnosis of leadership skills" E. Krushelnytsky, E. Zharikov. According to the results of this testing, a group of students with a high level of leadership skills was selected - 64 students, including 28 girls and 36 boys.

At the second stage, a study was conducted with the involvement of student leaders, for which the method "Diagnosis of the level of polycommunicative empathy" was used. Yusupova. A comparison was made based on the results of this technique.

The data obtained show that none of the males or females has a very high level of empathy. $9.09 \%$ of girls have a high level of empathy, so they are sensitive to the needs and problems of others, generous, able to forgive a lot, are interested in people; emotionally sensitive; try to avoid conflicts and find compromise solutions; tolerate criticism well; prefer to work with people; constantly need social approval for their actions. As for the boys, they do not have a high level. $70 \%$ of males and $81.82 \%$ of females have an average level of empathy, so in interpersonal relationships they are more likely to judge others by their actions than to trust their personal impressions; emotional manifestations are under self-control; in communication attentive, trying to understand more than what is said in words, when reading works of art and watching movies more often watch the action than the experiences of the characters; can not predict the development of relations between people, so it turns out that their actions are unexpected for them. Low prevalence among boys - 30\%, in turn for girls - 9.09\%, which means that respondents have difficulty establishing contact with people, feel uncomfortable in noisy company, emotional manifestations in the actions of others sometimes seem incomprehensible and devoid of sense; most often prefer separate activities to a specific 
case, rather than working with people; supporters of precise formulations and rational decisions; they have few friends, and those who are among them are valued for their clear mind and business acumen than for their sensitivity. A very low level of empathy was not found in this group of respondents.

Given the histogram data, we can trace the tendency that empathy is better developed in females than in males, presented in this sample. It should also be noted that a significant proportion of adolescents have an average level of empathy, which is typical of most people.

Empathy for animals is felt better by females (46.06\%) - medium level than males (37.33\%) - low level. We can say that internal mental objects are projected on animals. Accordingly, empathy for animals is empathy for oneself, feeling oneself through external objects. It is much more difficult for people to project their "inner world", so it is more difficult to interact with them in the same way.

Empathy for the elderly is better developed in boys (43.33\%) - medium level than in girls (38.18\%) - low level.

In empathy for children there are slight differences in favor of girls $(59.39 \%$ is dominated by the average level), boys have an average level of $48.66 \%$. Such differences may be due to the fact that about $70 \%$ of the girls in this sample are single in their family, ie do not have siblings. Accordingly, the older a child has older siblings, the less empathetic he or she is to other children.

Постановка проблеми у загальному вигляді та іiі зв'язок із важливими науковими чи практичними завданнями. Актуальність теми освітнього лідерства обумовлюється тим фактом, що стратегією розвитку вищої освіти України на 20212031 рік, лідерство визначається як один із важливих напрямків розвитку фахівця. Важко переоцінити роль освітнього лідерства в процесі формування сучасного фахівця. Дослідження, що проводяться по
In empathy for the heroes of works of art can be traced a significant difference in favor of girls (53.93\% average level). Such results can be explained by the lack of interest in fiction as a subject and reading as a way of structuring free time.

Empathy for strangers is better developed in females $(63.63 \%$ have a high level) than in men, where the most common is the middle level (54\%).

In general, on all scales of the method the level of empathy is higher in girls, except for the scale "Empathy for the elderly". Respondents of this sample have the best developed empathy for parents, which makes their contribution to the process of forming a young person's personality the most significant.

Conclusions of the research: The study found that empathy is one of the most important features in the personality structure of a modern student leader, and its formation should be given special attention in higher education institutions.

A study of leadership skills revealed that about $29 \%$ of students have high levels of leadership skills.

The analysis of gender peculiarities of the manifestation of the field of communicative empathy of students-leaders allowed to determine that empathy is better developed in girls than in boys. This poses an important task for practical psychologists of higher education institutions to create special training programs that would promote the development of empathy in student leaders.

всьому світу вказують на те, що студентське лідерство сприяе розвитку високих навчальних результатів, підприємницьких та комунікативних навичок. Цілеспрямовані програми розвитку лідерства сприяють створенню атмосфери більшого включення студентів до освітнього процесу [6]. При цьому дослідники погоджуються, що розвитку усіх цих показників могли сприяти не тільки програми 3 вдосконалення лідерства чи 
наявність виражених лідерів у групах, а й сприятливі умови для саморозвитку в кампусі чи активна соціальна взаємодія між учасниками освітнього процесу $[9,10]$.

Разом із тим дослідники з усього світу погоджуються 3 тим фактом, що студенти-лідери, які готові сміливо демонструвати свої погляди, позиції, переконання можуть виступати рольовими моделями для своїх послідовників. В цьому контексті надзвичайну роль відіграє здатність студентських лідерів не тільки усвідомлювати настрої та інтереси своїх послідовників, а й буквально відчувати їх. Таку здатність може забезпечити розвинена емпатія. Надмірно зосереджуючись на дослідженнях вольових, інтелектуальних якостей лідерів, дослідники часто забувають про те, що лідерство - це соціальний феномен, а його успіх залежить від якості міжособистісної комунікації між лідером та послідовниками, в основі чого лежить емпатія.

Аналіз останніх досліджень та публікацій, яких започатковано розв'язання цієї проблеми і на які спирається автор. Останні дослідження показують, що студентське лідерство - це досить неоднорідне явище, яке об'єднує осіб із різними характерами, прагненнями, цілями, усвідомленнями власної відповідальності. Дуже важливо, щоб тип лідерства, до якого належать студенти, сприяв конструктивному розвитку їхніх послідовників та створював умови для демонстрації позитивних моделей навчання. В своєму дослідженні ми спираємося на визначення лідерства, запропоноване О. Романовським: "Лідерство - це трьохкомпонентне явище: лідерство як особистість; лідерство як команда; лідерство як процес. Поєднання визначених компонентів забезпечує послідовний рух лідера та його команди до досягнення мети та реалізації поставлених завдань. Відсутність хоча 6 одного 3 компонентів приводить до блокування реалізації лідерського потенціалу особистості" [4, с. 7].

При визначенні типу освітнього лідерства надзвичайне значення має така характеристика студентських лідерів як емпатія. Найбільш широке визначення емпатії було запропоновано Р. Бар-Оном, який визначав іii як здатність глибоко відчувати емоційні стани, цілі та цінності інших людей, що супроводжується бажанням надавати іншим людям підтримку та допомагати за потребою [7].

В роботах Н. Підбуцької розглядається важливість емпатії в контексті становлення професіоналізму особистості. Дослідниця доводить, що емпатія як один із показників емоційної сфери людини відіграє визначальну роль у становленні зрілої особистості, що здатна демонструвати соціальну відповідальність та послідовність [2]. Студенти-лідери як ніхто потребують у розвиткові саме цієї сторони професіоналізму, адже від їхньої цілісності, відповідальності, здатності дотримуватися власних цінностей залежить не тільки їхній власний успіх, а й успіх їхніх послідовників [3].

В роботах Д. Гоулмана, присвячених проблемі емоційного лідерства, переконливо доводиться, що емпатія $\epsilon$ необхідним елементом будь-якого сучасного лідера. Лідер, що володіє навичками емпатії та може їх застосовувати, знаходиться не тільки у порозумінні зі своїми послідовниками, а ще й в доброму контакті з власними емоційними переживаннями. Емпатійність дозволяє лідеру приймати рішення, враховуючи різні характеристики соціальної ситуації та призначати на виконання завдань саме тих осіб, які скоріше за все досягнуть успіху [1]. Важливо, що автор не розглядає емпатію як надмірну чуйність та слабкість. Навпаки, він підкреслює, що емпатія робить лідера сильнішим i дозволяє отримувати більше інформації за міжособистісної взаємодії, а також викликати довіру у своїх послідовників.

В дослідженнях А. Черкашина та О. Романовського показано, що розвиток емпатії як компоненту емоційного інтелекту $\epsilon$ одним із найбільш визначних 
елементів підготовки студентів-лідерів в Україні [5, 8]. Система тренінгів, що розроблена на кафедрі педагогіки i психології управління соціальними системами під керівництвом О. Романовського передбачає формування емпатії під час тренінгової взаємодії.

Виділення невирішених раніше частин загальної проблеми, котрим присвячується дана стаття. Не враховуючи єдність думок вчених щодо важливості емпатії для сучасних лідерів, ми маємо констатувати повну відсутність досліджень, спрямованих на вивчення особливостей прояву різних видів емпатії у студентів-лідерів. Зокрема залишаються не вивченими гендерні особливості прояву полікомунікативної емпатії у студентів-лідерів.

Формування цілей статті (постановка завдання). Мета статті - представити результати дослідження гендерних особливостей полікомунікативної емпатії студентів-лідерів.

Основними завданнями дослідження були визначені:

- виділити підгрупи студентів- лідерів із використанням валідного психодіагностичного інструментарію;

- проаналізувати гендерні особливості прояву полікомунікативної емпатії студентів-лідерів.

Виклад основного матеріалу дослідження 3 повним обгрунтуванням отриманих наукових результатів. 3 метою реалізації мети та завдань статті нами було проведено дослідження за участі 214 студентів Національного технічного університету “Харківський політехнічний інститут”. Дослідження здійснювалося в два етапи.

На першому етапі було проведеного тестування студентів із використанням методики “Діагностика лідерських здібностей” Є. Жарікова, Є. Крушельницького. За результатами цього тестування було виділено групу студентів із високим рівнем лідерських здібностей - 64 студенти, серед яких 28 дівчат та 36 хлопців.

На другому етапі було проведено дослідження 3 залученням студентівлідерів, для якого було використано методику "Діагностика рівня полікомунікативної емпатії” І. Юсупова. За результатами цієї методики було виконано порівняння (рис. 1, 2).

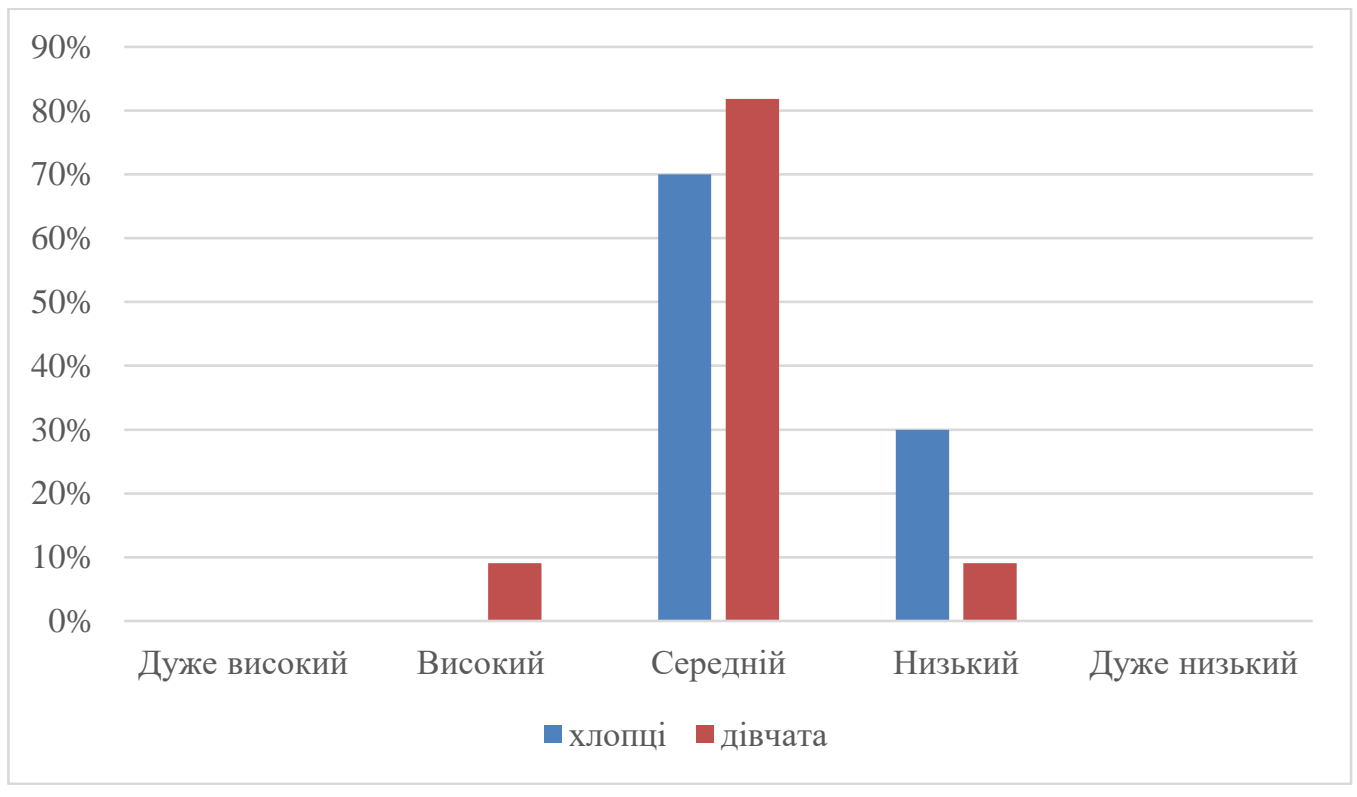

Рис. 1. Порівняння рівня емпатї хлопиів та дівчат (\%) 
Отримані данні свідчать про те, що жоден із представників чоловічої або жіночої статі не має дуже високого рівня емпатії. 9,09\% дівчат мають високий рівень емпатії, тому вони чутливі до потреб і проблем оточуючих, великодушні, здатні багато вибачати; з цікавістю ставляться до людей; емоційно чуйні; намагаються не допускати конфліктів i знаходять компромісні рішення; адекватно сприймають критику стосовно себе; віддають перевагу роботі з людьми; постійно потребують соціального схвалення своїх дій. Щодо хлопців, то у них високого рівня прояву не спостерігається. Середній рівень емпатії мають 70\% представників чоловічої статі та $81,82 \%$ жіночої, тому вони у міжособистісних відносинах більш схильні складати думку про інших за їхніми вчинками, ніж довіряти своїм особистим враженням; емоційні прояви знаходяться під самоконтролем; у спілкуванні уважні, намагаються зрозуміти більше, ніж сказано словами; при читанні художніх творів і перегляді фільмів частіше стежать за дією, ніж за переживаннями героїв; не можуть прогнозувати розвиток відносин між людьми, тому виходить, що їхні вчинки для них виявляються несподіваними. Низький рівень переважає у хлопців - 30\%, натомість у дівчат $-9,09 \%$, це означає, що респонденти відчувають труднощі у встановленні контактів із людьми, незатишно почуваються в галасливій компанії; емоційні прояви у вчинках оточуючих часом здаються незрозумілими і позбавленими сенсу; найчастіше віддають перевагу відокремленим заняттям конкретною справою, а не роботі 3 людьми; прихильники точних формулювань і раціональних рішень; у них мало друзів, а тих, хто в їх числі, цінують за ясний розум i ділові якості, ніж за чуйність. Дуже низький рівень емпатії не було виявлено в даній групі респондентів.

3 огляду на дані гістограми, можна простежити тенденцію, що у жіночої статі емпатія розвинена краще, ніж у чоловічої даної вибірки. Також треба зазначити, що значна частина підлітків має середній рівень емпатії, який притаманний більшості людей.

На рисунку 2 зображені результати по окремим шакалам методики I. Юсупова "Діагностика рівня полікомунікативної емпатіï”.

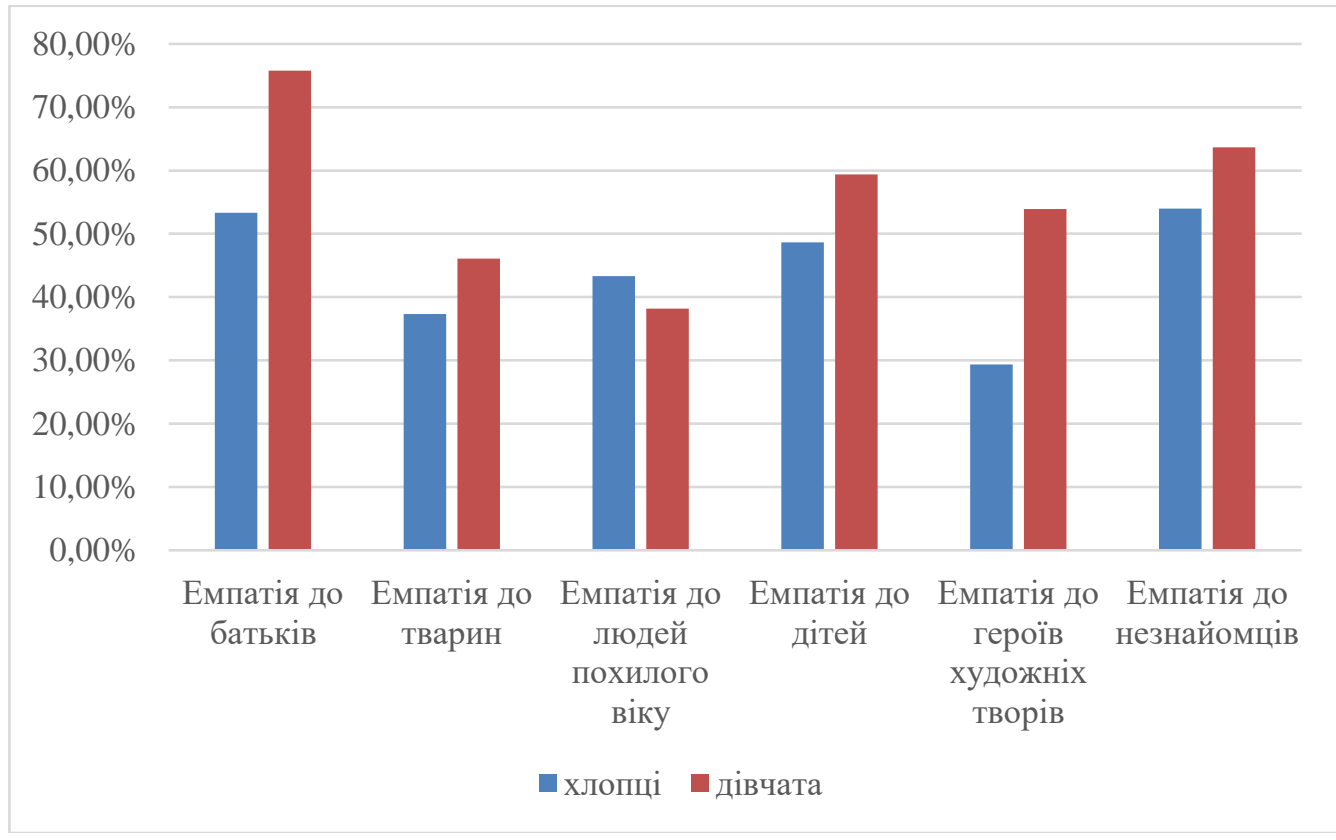

Рис. 2. Порівняння прояву емпатії хлопичів та дівчат (дані наведені у \%) 
Отримані дані, які відображені на рисунку 2 свідчать про відмінності емпатичних реакцій студентів-лідерів різних статей. Якщо говорити про емпатію до батьків, то у дівчат вона розвинена краще $(75,75 \%)$ - високий рівень, ніж у хлопців $(53,33 \%)$ - середній рівень. На цей показник та на емпатію в цілому може впливати стиль виховання, тому було проведено додаткове опитування на дану тему, що дозволило отримати такі данні:

- Хлопці: дозволяючий стиль виховання був виявлений у $20 \%$ студентівлідерів, авторитарний у $30 \%$ та авторитетний у $50 \%$.

- Дівчата: дозволяючий стиль виховання був у 9,09\% студенток-лідерок, авторитарний у 9,09\% та авторитетний у $81,81 \%$

Наведені вище дані свідчать про те, що більшість дівчат-лідерів виховувалися 3 використанням авторитетного стилю виховання, при якому батьки встановлюють теплі контакти 3 дитиною та розумно ii контролюють, а у половини хлопців дозволяючий та авторитарний, при якому в людини може формуватися антисоціальна поведінка.

Емпатію до тварин відчувають краще представниці жіночої статі $(46,06 \%)$ - середній рівень, ніж представники чоловічої $(37,33 \%)$ - низький рівень. Можна сказати, що на тварин проєктуються внутрішні психічні об'єкти. Відповідно, емпатія до тварин - це емпатія до самого себе, відчуття себе через зовнішні об'єкти. На людей набагато складніше проєктувати свій "внутрішній світ", тому таким же чином iз ними взаємодіяти складніше.

Емпатія до людей похилого віку краще розвинена в хлопців $(43,33 \%)-$ середній рівень, ніж в дівчат $(38,18 \%)-$ низький рівень.

В емпатії до дітей присутні незначні відмінності на користь дівчат (у 59,39\% переважає середній рівень), у хлопців середній рівень визначено у 48,66\%. Такі відмінності можуть бути пов'язані з тим, що приблизно 70\% дівчат із даної вибірки - єдині в своїй сім'ї, тобто не мають братів і сестер. Відповідно до цього твердження, чим більше у дитини старших братів і сестер, тим вона менше емпатична до інших дітей.

В емпатії до героїв художніх творів можна простежити значну відмінність на користь дівчат (у 53,93\% середній рівень). Такі результати можна пояснити недостатнім інтересом до художньої літератури як навчального предмета і читання як способу структурування вільного часу.

Емпатія до незнайомців краще розвинена у представниць жіночої статі (у $63,63 \%$ переважає високий рівень), ніж у чоловічої, де найбільш поширеним $\epsilon$ середній рівень (54\%).

Загалом, за всіма шкалам методики рівень емпатії вищий у дівчат, окрім шкали “Емпатія до похилих людей”. Найкраще у респондентів даної вибірки розвинене співчуття до батьків, що робить їхній внесок у формування особистості молодої людини найбільш значущим.

Виявлені особливості розкривають сутність емпатійних процесів у студентівлідерів, що відображаються на якості їхньої взаємодії з послідовниками.

Висновки 3 даного дослідження та перспективи подальших розвідок у даному напрямку. В ході дослідження було визначено, що емпатія $є$ однією 3 найбільш важливих рис в структурі особистості сучасного студентського лідера, а іiї формуванню має приділятися особлива увага в закладах вищої освіти.

Дослідження лідерських здібностей дозволило визначити, що близько $29 \%$ студентів володіють вираженими на високому рівні лідерськими здібностями.

Аналіз гендерних особливостей прояву полікомунікативної емпатії студентів-лідерів дозволив визначити, що у дівчат емпатія розвинена краще, ніж у хлопців. Це ставить перед практичними психологами закладів вищої освіти важ- 
ливе завдання створення спеціальних тренінгових програм, що сприяли б роз-

\section{Список літераури:}

1. Гоулман Д. Эмоциональное лидерство: Искусство управления людьми на основе эмоционального интеллекта / Дэниел Гоулман, Ричард Бояцис, Энни Макки; [пер. с англ.]. - М.: Альпина Бизнес Букс. - 2005. - С. 301

2. Підбуцька Н. В. Мотиваційна основа учіння майбутнього інженера / Н. В. Підбуцька // Педагогіка, психологія та медико-біологічні проблеми фізичного виховання і спорту. - 2007. - № 1. -С.94-98

3. Підбуцька Н. В. Особливості креативності майбутнього інженера як складової його професіоналізму / Н.В. Підбуцька // Проблеми сучасної психологіï $=$ Problems of Modern Psychology : зб. наук. пр. Кам'янецьПодільського нац. ун-ту ім. І. Огієнка, Інту психології ім. Г. С. Костюка НАПН України. - Кам'янець-Подільський : Аксіома. - 2014. - Вип. 26. - С. 468-477

4. Романовський О. Г. Теорія i практика формування лідера : навч. посібник / О. Г. Романовський, Т. В. Гура, А. С. Книш, В. В. Бондаренко; Нац. техн. ун-т "Харків. політехн. ін-т". - Харків : Друкарня Мадрид. - 2017. - С. 100

5. Черкашин А. І. Методологічні підходи до виховання особистості майбутніх фахівців-лідерів у закладах вищої освіти України / А. I. Черкашин // Теорія і практика управління соціальними системами. -2019 - № 2. - С. 60-72

6. Аббасі М. Х. Роль ефективних комунікацій для покращення лідерських i підприємницьких навичок у студентів університетів / Аббасі М. Х., Сіддікі А., Азім Р.У.А. // Міжнародний журнал бізнесу та соціальних наук. - 2011. - №2 (10), 9

7. Bar-On R. Emotional and social intelligence: Insights from the Emotional Quotient Inventory / R. Bar-On // R. Bar-On, J. D. A. Parker (eds.); Посібник 3 емоційного інтелекту. - Сан-Франциско: витку емпатії у студентів-лідерів.

Джоссі Басс. - 2000. - С. 363-388

8. Comparative analysis of leadership training concepts in high schools in the UK and Ukraine / O. Romanovsky [et al.] // Теорія і практика управління соціальними системами: філософія, психологія, педагогіка, соціологія. - 2016. - № 2. - С. 3-10

9. Калашнікова С. Розвиток університетського лідерства: уроки України / С. Калашнікова, О. Оржель // Міжнародний науковий журнал університетів i лідерства. - 2019. - №8. - С. 133-143

10. Луїс М. Лідерство та результативність у вищій освіті: порівняльний аналіз у Португалії та Іспанії / Луїс Мануель Серда Суарес та Вільмар Ернандес // Свропейський журнал інженерної освіти. - 2012. - №37:6. - С. 592-599

\section{References:}

1. Goleman, D. (2005), Эmotsyonalnoe lyderstvo: Yskusstvo upravlenyia liudmy na osnove эmotsyonalnoho yntellekta [Emotional Leadership: The Art of Managing People Based on Emotional Intelligence], Moscow, p. 301

2. Pidbutska, N. V. (2007), Motyvatsiina osnova uchinnia maibutnoho inzhenera [Motivational basis of learning of the future engineer], Pedagogy, psychology and medical and biological problems of physical education and sports,no. 1,pp.94-98

3. Pidbutska, N. V. (2014), Osoblyvosti kreatyvnosti maibutnoho inzhenera yak skladovoi yoho profesionalizmu [Features of creativity of the future engineer as a component of his professionalism], Problems of modern psychology: collection. Science. Kamyanets-Podilsky National Avenue University named after I. Ogienko, Institute of Psychology. GS Kostyuk NAPS of Ukraine, no. 26, pp. 468-477

4. Romanovsky, O. G. (2017), Teoriia i praktyka formuvannia lidera : navch. posibnyk [Theory and practice of leadership 
formation: textbook. Manual], Nat. tech. Kharkiv Polytechnic University, p. 100

5. Cherkashin, A. I. (2019), Metodolohichni pidkhody do vykhovannia osobystosti maibutnikh fakhivtsiv-lideriv $u$ zakladakh vyshchoi osvity Ukrainy [Methodological approaches to educating the personality of future specialists-leaders in higher education institutions of Ukraine], Theory and practice of management of social systems, no. 2, pp. 60-72

6. Abbasi, M. H., Siddiqi, A., \& Azim, R. U. A. (2011), Rol efektyvnykh komunikatsii dlia pokrashchennia liderskykh i pidpryiemnytskykh navychok u studentiv universytetiv [Role Of Effective Communications For Enhancing Leadership And Entrepreneurial Skills In University Students], International Journal of Business and Social Science, no. 2(10), 9

7. Bar-On, R. (2000), [Emotional and social intelligence: Insights from the
Emotional Quotient Inventory], Handbook of emotional intelligence, San Francisco: Jossey-Bass., pp. 363-388

8. Romanovsky, O. (2016), [Comparative analysis of leadership training concepts in high schools in the UK and Ukraine], Theory and practice of social systems management: philosophy, psychology, pedagogy, sociology, no. 2, pp. 3-10

9. Kalashnikova, S., \& Orzhel, O. (2019), [University leadership development: lessons from Ukraine], International Scientific Journal of Universities and Leadership, no.(8), pp. 133-143

10. Luis Manuel Cerda Suarez \& Wilmar Hernandez (2012), Liderstvo ta rezultatyvnist u vyshchii osviti: porivnialnyi analiz u Portuhalii ta Ispanii [Leadership and performance in higher education: a comparative analysis in Portugal and Spain], European Journal of Engineering Education, no. $37: 6$, pp. 592-599 